\title{
Assessment of Pollution Status of Soils and Vegetables Irrigated by Awash River and its Selected Tributaries
}

\author{
Tesfalem Belay* and Tizazu $\mathbf{H}$ \\ Ethiopian Environment and Forest Research Institute \& Central Ethiopia Environment and Forest Research Center, Ethiopia
}

Submission: April 03, 2019; Published: April 26, 2019

*Corresponding author: Tesfalem Belay, Ethiopian Environment and Forest Research Institute \& Central Ethiopia Environment and Forest Research Center, Ethiopia

\begin{abstract}
This assessment was done to determine the concentrations of Cadmium (Cd), Chromium (Cr), Copper (Cu), Lead ( $\mathrm{Pb})$ and Manganese (Mn) in soil and vegetable (Spinach) samples collected in some farmlands irrigated with Awash River. Graphite Furnace Atomic Absorption Spectrometer was used for analyzing heavy metal concentrations. The test results showed that in the soil samples, from five heavy $(\mathrm{Cd}, \mathrm{Cr}, \mathrm{Cu}, \mathrm{Mn}, \mathrm{and} \mathrm{Pb})$ metals $\mathrm{Cr}$ and $\mathrm{Mn}$ were detected in all the soil samples collected from farmlands in the Lower, Middle, and Upper Awash River Basin. However, Cu was detected only in soil samples collected from farmlands in the lower Awash River Basin. The order of heavy metals concentrations (mg/kg) in soil from Lower, Middle, and Upper Awash River basin, respectively, was: Mn (1027, 1118, 89.8), Cr (82.2, 67.2, 57.2), Cu (27.4, ND, ND), Cd and $\mathrm{Pb}$ (ND, ND, ND). The concentrations of $\mathrm{Cr}, \mathrm{Mn}$ and $\mathrm{Cu}$ analyzed in some of the soil sampling sites were below maximum permissible limits set for agricultural soils by (FAO/WHO: 2001). The vegetable (spinach) samples collected from same sites as the soil samples result showed that $\mathrm{Cr}$ and Mn were detected in all sites and $\mathrm{Cu}$ was detected only lower Awash River basin. The order of heavy metals concentrations (mg/kg) in soil from Lower, Middle, and Upper Awash River basin, respectively, were: $\mathrm{Cr}$ (89.8, 82.4, 125.6) Mn (535.8, 5.8, 67, Cu (6.4, ND, ND), Cd (Not Detected, ND, $\mathrm{ND})$ and $\mathrm{Pb}(\mathrm{ND}, \mathrm{ND}, \mathrm{ND})$. The soil-to-plant transfer factor (Kd) order was found to be $\mathrm{Cr}(1.094,1.23,2.2)>\mathrm{Mn}(0.52,0.01,0.73)>\mathrm{Cu}(0.23)$. The concentrations of the metals analyzed in some of the vegetable sampling sites were above maximum permissible limit set for vegetables by (FAO/WHO; 2001). Therefore, the consumption of Spinach from the farmlands irrigated by Awash River could pause a health risk to consumers. Therefore, it is advised that consumers become cautious of their vegetable consumption. It is recommended that this kind of assessment is continued to monitor changes in the future.
\end{abstract}

Keywords: Awash River; Contamination; Trace elements; Vegetables; Soil

\section{Introduction}

Soil ecology has been defined as the study of natural fluctuations in soil processes and populations of soil organisms. Soil ecosystems are incredibly complex with great heterogeneity in physical, chemical and biological characteristics and are considerably influenced by factors such as geology, topography, climate and anthropogenic activities [1,2]. Soil is an environmental, biochemical reaction system with three important phases: solid (i.e. mineral particles, organic debris, plant roots), Liquid/solution (i.e. groundwater, rain water, biological excreta, products of biochemical reactions), and gas (i.e. atmospheric, products of biochemical reactions) which move towards equilibrium with one another. Agricultural soil is mentioned to be the most important sink for heavy metals due to soils high metal retention capacities [3]. There is evident to indicate that agriculture soil also has increased levels of heavy metals as a result of increased in anthropogenic activities. The chemical constituents of irrigation water can affect plant growth directly through toxicity or deficiency, or indirectly by altering plant availability of nutrients [4]. Waste water carries appreciable amount of trace toxic metals which often leads to degradation of soil health and contamination of food chain mainly through the vegetable grown on such soils. The toxic elements accumulated in organic matter in soil are taken up by growing plants and lastly exposing humans to this contamination [5]. The risk and health implications of polluted soils for crop production detailed that the source of heavy metal in plant is the environment in which they grow and their growth medium, the soil, from which heavy metals are taken up by roots or foliage of plants [6]. Potentially harmful metal in soils may come not only from the bedrock but also from anthropogenic sources like solid or liquid wastes, atmospheric sources, surface runoff, mining of coal and ore, agricultural inputs, landfill leachate and fallout of industrial and urban emissions $[7,8]$. Vegetables are major components of human diet, being sources of essential nutrients, antioxidants and metabolites in food items. The flow of trace heavy metals between the soil, plants, water and the 
atmosphere are the part of a complex and complicatedly connect biogeochemical cycling processes in nature. In addition to the natural weathering, anthropogenic activities are significantly responsible for elevated trace metals concentrations in soils [9]. Living organisms (plants, animals and microorganisms), store and transport metallic elements, both to provide appropriate concentrations of them for later use in metallo-proteins or cofactors and to protect themselves against the toxic effects of metal excess. Growth media including soil, nutrient solution, water and air are main sources of heavy metals to vegetables and other crops, which enter by roots or foliages through two main bio-sorption mechanisms: adsorption and/or absorption and accumulated in their tissues $[10,11]$. Different vegetable species accumulate different metals depending on environmental conditions, metal species and plant, available forms of the heavy metals [12]. Many plants are found to be able to take up large quantities of certain elements from the environment and said hyper-accumulators of heavy metals [13].

Table 1: Standard limits of some heavy metals in the soil and Vegetables.

\begin{tabular}{|c|c|c|}
\hline Parameters & $\begin{array}{c}\text { Standard Limits of } \\
\text { Heavy Metals in Soil } \\
\text { Samples mg/kg }\end{array}$ & $\begin{array}{c}\text { Standard Limits of Heavy } \\
\text { Metals in Vegetable } \\
\text { Samples mg/kg }\end{array}$ \\
\hline $\mathrm{Pb}$ & 100 & 0.3 \\
\hline $\mathrm{Cr}$ & 100 & 2.3 \\
\hline $\mathrm{Cd}$ & 3 & 0.2 \\
\hline$* * \mathrm{Mn}$ & 2000 & 500 \\
\hline$* * \mathrm{Cu}$ & 100 & 73.3 \\
\hline
\end{tabular}

These plants have been on use even as phytoremediation, removing or transforming contaminants through metabolic processes [14]. Metal uptake by plants can be affected by several factors including metal concentrations in soils, soil pH, cation exchange capacity, organic matter content, types and varieties of plants, and age of the plant [15].

The chemical forms of metals in which they enter the ecosystems and their final forms of existence greatly affect mobility, bio-availability, storage, retention and toxicity of the metals in living organisms, food and the environment [16]. Many studies have shown that waste water irrigation has elevated the levels of heavy metals in receiving soils $[17,18]$. The vegetable from the contaminated soil can accumulate some high concentration of heavy metal and cause some serious risk to human health [19].

Awash River, which flows from central highland Ethiopia Central rift valley through Ethiopia's major industrial and agroindustrial belt, taking in a whole burden of all types of raw effluents. This study is intended at assessing the concentration of $\mathrm{Mn}, \mathrm{Cd}, \mathrm{Cr}, \mathrm{Cu}$ and $\mathrm{Pb}$ and the pollution status of the irrigated soils of the farmlands and some vegetables grown irrigated with Awash River and its selected tributaries (Table 1).

\section{Materials and Methods}

\section{Description of the study area}

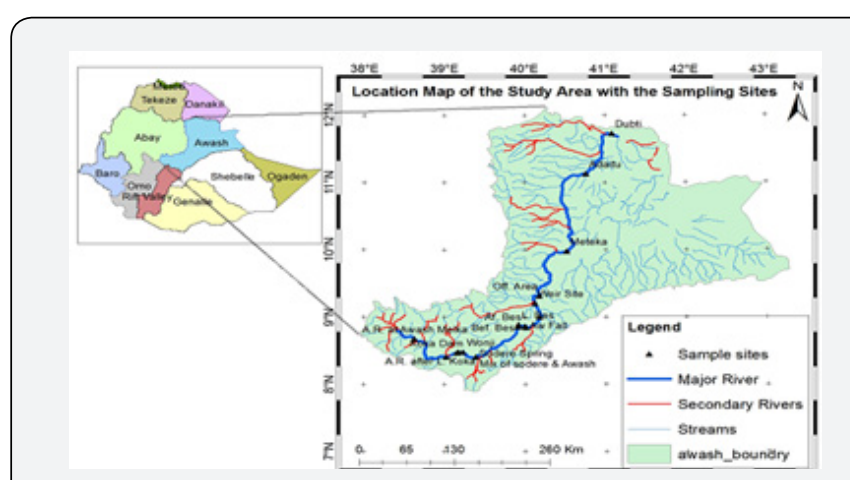

Figure 1: Location map of the study sites.

Awash River Basin, with a total catchment area of $113,304 \mathrm{~km}^{2}$, is located between latitudes $7^{\circ} 53^{\prime} \mathrm{N}$ and $12^{\circ} \mathrm{N}$ and longitudes $37^{\circ} 57^{\prime} \mathrm{E}$ and $43^{\circ} 25^{\prime} \mathrm{E}$ in Ethiopia (Figure 1). The Awash River originates from the high plateau Ginchi of 3000 m.a.s.l, $80 \mathrm{~km}$ west of Addis Ababa and terminates, after travelling about $1200 \mathrm{~km}$, at Lake Abe of $250 \mathrm{~m}$.a.s.l., at the border of Ethiopia and Djibouti [20-22]. With extreme ranges of topography, vegetation, rainfall, temperature and soils, the basin extends from semi-desert lowlands to cold high mountain zones. Land use in the catchment is mainly agricultural and shrub lands used for rain-fed crops, irrigation and grazing. Various crops are cultivated ranging from cereals, vegetables, flowers, cotton to perennial fruit trees and sugarcane $[20,23]$.

\section{Sampling design}

The assessment was conducted to assess the concentration of heavy metals on the soil and vegetables. The vegetables grown at the lower, middle and upper Awash River basin of some farmlands irrigated with Awash River and its tributaries. The Composite soil and vegetable samples were collected during March 2018 from Awash River basin available vegetables samples. The Composite soil and vegetable samples were analyzed for heavy metals. Cadmium (Cd), lead ( $\mathrm{Pb}$ ), Manganese $(\mathrm{Mn})$ and chromium ( $\mathrm{Cr}$ ) and copper concentrations using Graphite furnace atomic absorption spectroscopy.

\section{Sampling}

\section{Sampling of soil samples}

Composite soil samples (about $1 \mathrm{Kg}$ ) were collected the soil sub-samples were obtained from $0-20 \mathrm{~cm}$ depth from the site (Lower, middle and upper Awash River basin and its tributaries) where the vegetables were grown with an auger [24]. Then the samples were placed in clean polyethylene bags and transported to the CEEFRC Lab for pretreatment and analysis. Larger particles and other debris were removed from the soil and then soil samples were air dried in a dry and dust free place at room temperature for 5 days. The samples were then ground with mortar and pestle to pass through a $2 \mathrm{~mm}$ sieve and 
homogenized. The dried, sieved, and homogenized soil samples were placed in polyethylene bags until the time of digestion.

\section{Sampling of vegetable samples}

The common vegetables grown in the study area was spinach. Fresh spinach sample was collected from the soil sampling Lower Awash River basin (2 sites) Middle Awash River basin (2 sites) upper Awash River basin (3sites) using a random sampling technique method. For similar studies [25] matured leaves of spinach were sampled at early maturity methods. About $500 \mathrm{~g}$ of composite vegetable samples were made cut into pieces using alcohol disinfects scissors and packed into sterilized plastic polythene bags [26] and transported to laboratory processing.

\section{Sample preparation and analysis}

\section{Extraction and analysis of heavy metals in soil samples}

The $0.5 \mathrm{~g}$ dried and homogenized soil samples were transferred in to $100 \mathrm{~mL}$ digestion flask. In each of these flasks, $15 \mathrm{~mL}$ of a mixture $\mathrm{HNO}_{3}(69 \%)$ and $37 \% \mathrm{HCl}$ with volume ratio of $3: 1$ were added. The sample dissolved in the acid mixture was digested by hot plat in the digestion hood (at $80^{\circ} \mathrm{C}$ ) for $3 \mathrm{~h}$ and kept to cool. The mixture was filtered out through What man No. 42 filter paper to a $100 \mathrm{~mL}$ volumetric flask and finally diluted to the mark with distilled water [27-29]. The varying filtrates obtained above were analyzedthe total heavy metal content $(\mathrm{Cr}$, $\mathrm{Mn}, \mathrm{Cu}, \mathrm{Cd}$, and $\mathrm{Pb}$ ) by GFAAS in Jije laboglass Laboratory.

\section{Extraction and analysis of heavy metals in spinach}

The edible portions of spinach were carefully rinsed with distilled water to remove surface contamination. They were sliced using a knife and air dry on clean surfaces to eliminate excess moisture. The samples were oven dried at $70^{\circ} \mathrm{C}$ for $24 \mathrm{~h}$. The vegetable samples were weighed and ground in a pestle and mortar and store in clean dry Stoppard containers. $0.5 \mathrm{~g}$ vegetable samples were digested in $15 \mathrm{ml}$ of $\mathrm{HNO} 3(69 \%)$ and $\mathrm{HCl}(37 \%)$ mixtures (3:1) at $80^{\circ} \mathrm{C}$ until a transparent solution were obtained (Logan T. J and Miller R.H.,1983). These transparent solutions were then filtered through Whatman filter paper number 42 and diluted to $50 \mathrm{ml}$ with distilled water. The concentrations of heavy metals, cadmium (Cd), lead (Pb), Manganese (Mn), Copper $(\mathrm{Cu})$ and chromium $(\mathrm{Cr})$ in the filtrate were determined by using Graphite furnace atomic absorption spectroscopy method (AAS) [30].

\section{Data analysis}

In this assessment, data was computed using SPSS software version 20 for heavy metal analysis. The recorded data was subjected to analysis of variance (ANOVA) to assess the effect and concentrations of heavy metal contaminant in the vegetables tested. As the level of heavy metal contamination might vary with sample collection site. SPSS was used to test the existence of significant difference between the data. In all statistical analyses, confidence level was held at $95 \%$ and $\mathrm{P}<0.05$ was considered as significant.

\section{Results and Discussion}

\section{Heavy metal concentrations in soil}

Table 2: Concentration of heavy metals $(\mathrm{mg} / \mathrm{kg})$ in the soil from farmlands irrigated with Awash River.

\begin{tabular}{|c|c|c|c|c|c|}
\hline Sampling Sites & Cd & Pd & Cr & Mn & Ca \\
\hline Lower awash River Basin & ND & ND & 82.2 & 1027 & 27.4 \\
\hline Middle awash River Basin & ND & ND & 67.2 & 1118 & ND \\
\hline Upper Awash River Basin & ND & ND & 57.2 & 89.8 & ND \\
\hline St.limited & 3 & 100 & 100 & 2000 & 100 \\
\hline
\end{tabular}

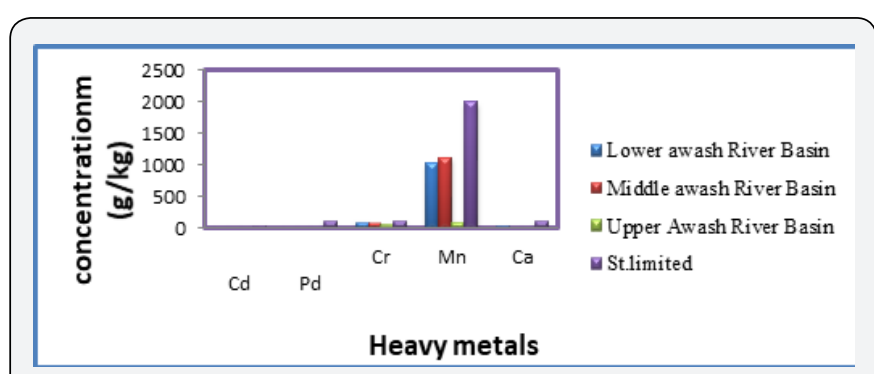

Figure 2: Concentration of heavy metals $(\mathrm{mg} / \mathrm{kg})$ in the soil from farmlands irrigated with Awash River.

The concentrations of heavy metals found in the irrigated farmland soil samples are presented in Table 2 and Figure 2. The soil samples from lower, middle and upper Awash River basin revealed high concentration of $\mathrm{Cr}$ and $\mathrm{Mn}$. However, $\mathrm{Cu}$ was found only in soils from farmlands located at the lower River of Awash Basin. $\mathrm{Pb}$ and $\mathrm{Cd}$ were not detected in all soil sampling sites. The overall results ranged $\mathrm{Cr}$ (57.2-82.2) mg/kg, Mn (89.81118) $\mathrm{mg} / \mathrm{kg}$ and $\mathrm{Cu}$ in lower wash River basin (27.4) mg/kg. The results showed that the concentration of $\mathrm{Mn}$, Crand $\mathrm{Cu}$ detected in the soil samples were below maximum permissible limits set for agricultural soils by [31].

\section{Heavy metal concentrations in spinach}

Table 3: Heavy metals concentration $(\mathrm{mg} / \mathrm{kg})$ in selected vegetables (spinach) irrigated with Awash River.

\begin{tabular}{|c|c|c|c|c|c|}
\hline Sampling Sites & $\mathbf{C d}$ & $\mathbf{P b}$ & $\mathbf{C r}$ & $\mathbf{M n}$ & $\mathbf{C u}$ \\
\hline Lower Awash River Basin & ND & ND & 89.8 & 535.8 & 6.4 \\
\hline Middle Awash River Basin & ND & ND & 82.4 & 5.8 & ND \\
\hline Upper Awash River Basin & ND & ND & 125.6 & 67 & ND \\
\hline St. limited & 0.2 & 0.2 & 2.3 & 200 & 73 \\
\hline
\end{tabular}

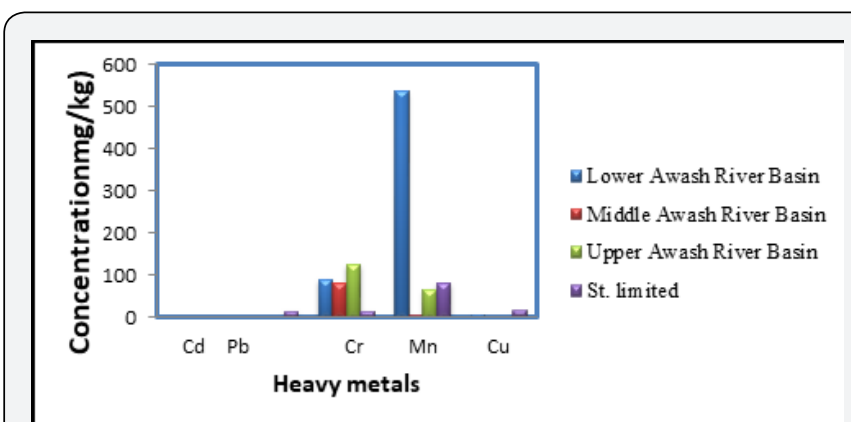

Figure 3: Heavy metals concentration $(\mathrm{mg} / \mathrm{kg})$ in selected vegetables (spinach) irrigated with Awash River. 
Heavy metal concentrations in vegetable samples from the study sites were shown in (Tables 3 and Figure 3). The data presented were restricted to the edible parts of the vegetable. Generally, vegetables harvested in soil presented higher concentration of $\mathrm{Cr}$ metal but lower concentration of $\mathrm{Mn}$ and $\mathrm{Cu}$ metals when compared to those concentrations found in in the soil samples (Table 2). The test vegetables have the potential of showing variable uptake of the metals from the soils. The uptake of metal ions has been shown to be influenced by the metal species and vegetable parts [32]. The overall results ranged $\mathrm{Cr}$ (82.4-125) mg/kg, Mn (5.8-535.8) mg/kg and $\mathrm{Cu}$ in lower wash River basin (6.4) $\mathrm{mg} / \mathrm{kg}$ but $\mathrm{Cd}$ and $\mathrm{Pb}$ were not detected in all Vegetable sample sites. The results showed that the concentration of $\mathrm{Cr}$ in the three Awash basin and manganese at the lower Awash basin detected in the Vegetable samples were above maximum permissible limits set vegetables, by (FAO/ WHO) [31].

\section{Soil-to-Vegetable transfer factor (TF) of heavy metals}

The soil-to-plant transfer factor is one of the key components that determine human exposure to metals through the food chain. Generally, transfer factor expresses the bioavailability of a metal at a position on a species of plant [33]. Transfer factor is the ratio of the concentration of metal in the plant to that of the soil. The metal concentrations in the extracts of the soil and vegetables were calculated based on dry weight using the following simplified equation.

Table 4: Soil -Vegetables Transfer factors of heavy metals.

\begin{tabular}{|c|c|c|c|c|c|}
\hline Sampling Sites & $\mathbf{C d}$ & $\mathbf{P b}$ & $\mathbf{C r}$ & $\mathbf{M n}$ & $\mathbf{C u}$ \\
\hline Lower Awash River Basin & - & - & 1.094 & 0.522 & 0.23 \\
\hline Middle Awash River Basin & - & - & 1.23 & 0.01 & - \\
\hline Upper Awash River Basin & - & - & 2.2 & 0.75 & - \\
\hline
\end{tabular}

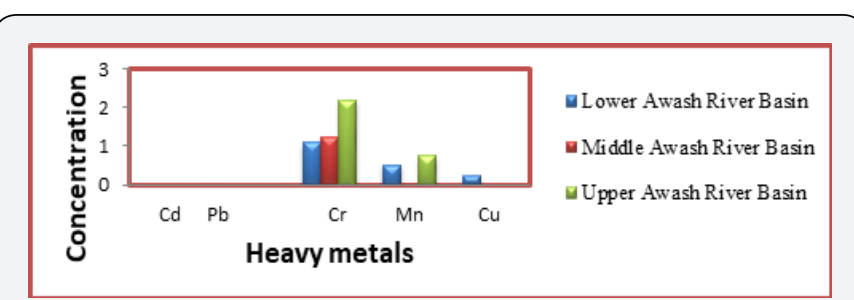

Figure 4: Soil -Vegetables Transfer factors of heavy metals.

Here, $\mathrm{Cp}$ and Cs are respectively the concentration of heavy metals analyzed in plant and soil samples (Table 3). As the calculated results, If the ratios $>1$, the plants have accumulated elements, the ratios around 1 indicate that the plants are not influenced by the elements, and ratios $<1$ show that plants avoid the elements from the uptake. In the present study, the TF of different heavy metal from soil to vegetable are presented in Table 3. Higher transfer factors reflect relatively poor retention in soils or greater efficiency of vegetables to absorbs metals. The TF value ranges were $\mathrm{Cr}$ (1.094-2.2) $\mathrm{Mn}$ (0.01-0.75) and $\mathrm{Cu}$ $(0.23)$ and the trend of TF for heavy metal in vegetable samples studied were in order: $\mathrm{Cr}>\mathrm{Mn}>\mathrm{Cu}$. The mobility of metals from soil to plants is a function of the physical and chemical properties of the soil and vegetable species and is altered by innumerable environmental and human factors [34]. The highest TF value was found 2.2 for Cr. These might be due to higher mobility of heavy metal with a natural occurrence in soil [20] and low retention in the soil than other toxic cations [35]. According to the soil to plant transfer factor (TF) calculated for tested metals and leafy vegetables consumed by residents, it can be concluded that $\mathrm{Cr}$ was high accumulator among the investigated metals. However, the higher concentrations of these heavy metals are due to the, waste disposal, sludge applications, agrochemicals, industrial waste, fertilizer application and other organic manure [36-38] (Table 4 \& Figure 4).

\section{Conclusion}

High concentration of heavy metals in the soil led to accumulation of heavy metals in the vegetables. In this study heavy metal concentrations varied among the sample sites, which reflect the differences in their uptake capabilities and their further translocation to edible portion of the plants. The metals ( $\mathrm{Cd}, \mathrm{Cu}, \mathrm{Mn}, \mathrm{Cr}$ and $\mathrm{Pb}$ ) investigated in this study were $\mathrm{Cd}$ and $\mathrm{Pb}$ were not detected in all sample sites of soil and vegetable samples and $\mathrm{Cu}$ at the upper and middle streams were not detected, but the concentrations of $\mathrm{Cr}$ and $\mathrm{Mn}$ in all sampling sites and $\mathrm{Cu}$ in the lower stream the soil samples studied were below and in the vegetable samples were above the recommended safe limits of heavy metals by (WHO/FAO; CAC; 2001). In all the heavy metals chromium is high concentration in the vegetable samples of upper stream (Modjo, aba samuel and leather) mainly as result of various industrial activities. The soil- vegetable transfer factor of heavy metal (Cr) is highly uptake by spinach. Thus, heavy metal accumulation in vegetables detected was severe and has potential to cause health risk to the communities consuming these vegetables frequently since these metals tend to bio-accumulate in consumers bodies. There is possible health risk to consumers of the vegetable planted in the area. Long term consumption of these metal-contaminated vegetables can cause different disease like Brain and Kidney damage, cancer in human body, dermatitis. Therefore, the integrated pollution management is highly required and prevention measures and regular monitoring should be enforced on those industries contributing to Awash River pollution.

\section{References}

1. Torstensson L (1997) Microbial assays in soils. In: Tarradellas J, Bitton G, Rossel D (Eds.), Soil Ecotoxicology. CRC Lewis, Boca Raton, FL, pp. 207-234.

2. Torstensson, L, Pell M, Strenberg B (1998) Need for a strategy for evaluation of arable soil quality. Ambio 27: 4 -8.

3. Tokalioglu S, Kartal S, Gultekin A (2006) Investigation of Heavy metal uptake by vegetables growing in contaminated soils using the modified BCR sequential extraction method. International Journal of Environmental Analytical Chemistry 86(6): 417-430. 
4. Ayers DM, Westcot RS (1985) Water Quality for Agriculture. FAO, Irrigation and Drainage Paper. 29: FAO, Rome, Italy, pp. 1-140.

5. Agrawal R, Sharma RK, Singh RP (2007) Contaminated Irrigation Water and Food Safety for the Urban and Peri-urban Poor: Appropriate Measures for Monitoring and Control from Field Research in India and Zambia, Incpetion Report DFID Enkar R8160, SPRU, University of Sussex, UK.

6. Okonkwo NE, Igwe JC, Onwuchekwa EC (2005) Risk and health implications of polluted soils for crop production. African Journal of Biotechnology 4(13).

7. Wilson B, Pyatt FB (2007) and Heavy metal dispersion, persistence, and bioaccumulation around an ancient copper mine situated in Anglesey, UK. Ecotoxicol Environ Saf 66(2): 224-231.

8. Zarazua G, Avila-Perez P, Tejeda S, Barcelo I, Martinez T (2006) Analysis of total and dissolved heavy metals in surface water of a Mexican polluted river by Total reflection X-ray Fluorescence Spectrometry, Spectrochimica Acta Part B: Atomic Spectroscopy 61(10-11): 11801184.

9. Devkota B, Schmidt GH (2000) Accumulation of heavy metals in food plants and grasshoppers from Taigetos Mountains, Greece. Agric Ecosyt Environ 78(1): 85-91.

10. Adeyeye EI (2005) Distribution of Major elements (Na. K, Ca, Mg) in the various anatomical parts of Fadama crops in Ekiti state, Nigeria. Bulletin of Chemical Society of Ethiopia 19(2): 175-183.

11. Abdullahi MS, Uzairu A, Okunola OJ (2008) Determination of Some Trace Metal Levels in Onion Leaves from Irrigated Farmlands on the Bank of River Challawa, Nigeria. African Journal of Biotechnology 7(10): 1526-1529.

12. Lokeshwari H, Chandrappa GT (2006) Impact of Heavy Metal Contamination of Bellandur Lake on Soil and Cultivated Vegetation, Current Science 91(5): 622-627.

13. Olajire AA, Ayodele ET (2003) Study of Atmospheric Pollution Levels by Trace Elements Analysis of Tree Bark and Leaves. Bulletin of Chemical Society of Ethiopia 17(1): 11-17.

14. Chamley H (2003) Fertlizers and Pesticides. Geosciences, Environment and Management. Elsevier Science, Netherlands.

15. Jung MC (2008) Heavy Metal Concentrations in Soils and Factors Affecting Metal Uptake by Plants in the Vicinity of a Korean Cu-W Mine. Sensors 8(4): 2413-2423.

16. Mocko A, Wacławek W (2004) Three-Step Extraction Procedure for Determination of Heavy Metals Availability to Vegetables. Anal Bioanal Chem 380(5-6): 813-817.

17. Singh S, Kumar M (2006) Heavy metal load of soil, water and vegetables in peri-urban Delhi. Environ Monit Assess 120(1-3): 79-91.

18. Sharma RK, Agrawal M, Marshall F (2006) Heavy metal contamination in vegetables grown in wastewater irrigated areas of Varanasi, India. Bull Environ Contam Toxicol 77(2): 312-318

19. Habib MN, Sarmin S, Nashir Uddin M, Rebeca G, Shamsun N (2011) Heavy metal levels in vegetables with growth stage and plant species variations. Bangladesh J Agril Res 36(4): 563-574.

20. Tessema SM (2011) Hydrological modeling as a tool for sustainable water resources Management: a case study of the Awash River Basin. Doctoral dissertation, KTH Royal Institute of Technology, Sweden.

21. Berhe FT, Melese AM, Hailu D, Sileshi Y (2013) MODSIM-based water allocation modeling of Awash River Basin, Ethiopia. Catena 109: 118128
22. Degefu F, Lakew A, Tigabu Y, Teshome K (2013) The water quality degradation of upper Awash River, Ethiopia. Ethiop J Environ Stud Manag 6(1): 58-66.

23. Gedion T (2009) Surface Water-Groundwater Interactions and Effects of Irrigation on Water and Soil Resources in the Awash Valley. Dissertation, Addis Ababa University, Ethiopia.

24. Poggio M, Hepperle E, Marsan FA (2008) Metals pollutions and human bioaccessibility of topsoils in Grugliasco, Italy. Environ Pollut 157(2): 680-689.

25. Fisseha I (1998) Metal concentrations of some vegetables irrigated with industrial liquid waste at Akaka, Ethiopia. Ethiop J Sci 21(1): 133144.

26. Okafo CN, Umoh VI, Galadima M (2003) Occurrence of Pathogens on Vegetables Harvested from Soils Irrigated with Contaminated Streams. Sci Total Environ 311(1-3): 49-56.

27. Loon JC (1985) Selected methods of trace metal analysis biological and environmental samples. New York 5: 3685-3689.

28. Tsade H (2012) Determination of copper, zinc, cadmium, and lead concentrations in traffic density roadside soils in some selected town of east Ethiopia. MSc. Graduate project, Haramaya University, Haramaya, Ethiopia.

29. Hussien K (2015) Chemical fractionation of some trace heavy metals $(\mathrm{Cd}, \mathrm{Cr}, \mathrm{Cu}$ and $\mathrm{Pb})$ in some selected farm lands of Haramaya Woreda, Ethiopia. MSc. Graduate project, Haramaya University, Haramaya, Ethiopia.

30.APHA (2005) Standard methods for the examination of water and wastewater, $21^{\text {st }}$.

31. FAO/WHO (2001) Food additives and contaminants. Joint Codex Alimentarius Commission, FAO/WHO Food standards Programme, ALINORM 01.

32. Juste C, Mench M (1992) Long-term application of sewage sludge and, its effects on metal uptake by crops. In: Adriano DC (Ed.), Biogeochemistry of Trace Metals. CRC Press, Boca Raton, pp. 1992, 159-194.

33. Tsafe AI, Hassan LG, Sahabi DM, Alhassan Y, Bala BM (2012) Evaluation of heavy metals uptake and risk assessment of vegetables grown in Yargalma of northern Nigeria. Journal of Basic and Applied Scientific Research 2(7): 6708-6714.

34. Alloway BJ, Ayres CD (1997) Chemical principals of environmental pollution. ( $\left.2^{\text {nd }} \mathrm{edn}\right)$ Blackie Academic and Professional, London.

35. Zurera G, Estrada B, Rincón F, Pozo R (1987) Lead and cadmium contamination levels in edible vegetables. Bull Environ Contam Toxicol 38(5): 805-812.

36. FAO (Food and Agriculture Organization) (1985) Water quality for agriculture. FAO Irrigation and Drainage Paper No. 29 (Rev. 1). Rome, Italy, pp. 1-140.

37. FAO (Food and Agriculture Organization) (1992) Cropwat: A Computer Program for Irrigation Planning and Management: Irrigation and Drainage Paper. No. 45. FAO, Rome.

38. WHO (World Health Organization) (1989) Health Guidelines for the Use of Waste water in Agriculture and Aquaculture? Report of a Scientific Group Meeting. Technical Report Series, No. 778, World Health Organization, Geneva. p. 74. 
(C) This work is licensed under Creative DOI: 10.19080/IJESNR.2019.18.556000
Your next submission with Juniper Publishers will reach you the below assets

- Quality Editorial service

- Swift Peer Review

- Reprints availability

- E-prints Service

- Manuscript Podcast for convenient understanding

- Global attainment for your research

- Manuscript accessibility in different formats ( Pdf, E-pub, Full Text, Audio)

- Unceasing customer service

Track the below URL for one-step submission https://juniperpublishers.com/online-submission.php 